\title{
Ontologi Demokrasi
}

\section{Zulfirman}

\section{Abstrak}

Conceptually, democratic ontology is universal, however in the implementation of democratic ontology is mostly affected by the values of the truth and also the attitude of human being to the others in the society. Consequently, on the opearational level, democracy under the declarative and oftative perspective is easily changes. It tends to follow the normative language which relates to the meaning of the truth and attitude of the human being obeyed by a certain society.

\section{Pendahuluan}

Kata demokrasi adalah kata yang menggoda dan telah menjadi subjek diskusi yang intensif di belahan dunia ini. Rasa puas dan kecewa terhadap demokrasi telah menimbulkan perdebatan dan gugatan sengit dari waktu ke waktu. Klaim bahwa demokrasi sebagai sistem pemerintahan yang baik dan benar yang dianut oleh negara maju dan berkuasa membuat demokrasi itu menjadi kata yang di puja sekaligus dicerca.

Realitas menunjukkan, suatu negara atau seseorang melaksanakan kekuasaannya sesuai dengan pemahamannya atas demokrasi sebagai sistem pemerintahan yang baik, tidak sungkan-sungkan melakukan tindakan kekerasan dan pelanggaran kedaulatan negara lainnya dengan alasan negara tersebut telah melanggar nilai-nilai demokrasi. Atau, penguasa suatu negara acap kali melakukan tindakan penindasan terhadap masyarakat, rakyat yang dikuasainya, dengan alasan demi menegakkan demokrasi.
Pengaktualisasian nilai-nilai dasar demokrasi dalam praktik sejarah politik, ketatanegaraan, dan hukum di Indonesia temyata menimbulkan berbagai alternatif penafsiran melahirkan berbagai konsep demokrasi, yaitu (a) demokrasi liberal atau demokrasi parlementer dari tahun 1950 - 1958 (b) demokrasi terpimpin dari tahun 1959 - 1965, dan (c) demokrasi Pancasila dari tahun 1966 - 1998, dan (d) demokrasi sebagai reaksi terjadinya reformasi di Indonesia sejak 1998 hingga sekarang.

Dari sejarah praktik politik tersebut terlihat, bahwa makna demokrasi dan mekanisme demokrasi di Indonesia tidaklah bermakna baku. Beragamnya makna yang diberikan atas demokrasi memunculkan dinamika dalam ketatanegaraan Indonesia yang mempengaruhi ketentuan yuridis formal sebagaimana terlihat di dalam UUD yang pemah berlaku di indonesia, yaitu (a) UUD 1945 (b) UUD RIS (c) UUDS 1950, dan (c) UUD 1945 yang di amandeman. Di samping itu, penerapan demokrasi juga menimbulkan dinamika politik yang ditandai 
dengan berbagai peristiwa berskala nasional, antara lain dapat dilihat dari peristiwa Madiun, Pemberontakan DIITII, Pemberontakan G30S PKI, dan terakhir gerakan reformasi yang terjadi pada bulan Mai 1998.

Beragamnya penafsiran atas demokrasi yang melahirkan multitafsir tentang makna demokrasi, hal ini akan menimbulkan dampak dalam penerapannya sehingga masingmasing pihak politisi, penguasa, maupun pembentuk dan penegak hukum mempunyai pengertian sendiri-sendiri tentang makna demokrasi, akibatnya dalam penerapannya tidak terdapat kepastian dan mancapai tujuan sejati dari demokrasi itu sendiri.

Pemujaan dan pengkultusan terhadap kata demokrasi tanpa pemahaman yang sama telah memicu pergolakan secara internal dari suatu negara tertentu yang berkepanjangan, seperti di Miyanmar, Thailand, peristiwa di Perancis baru-baru ini yang menimbulkan kerusuhan secara nasional bahkan menjalar ke negara-negara tetangga di Eropa, demikian juga yang terjadi di Indonesia ditandai dengan lahirnya reformasi.

Hakikat lahirnya reformasi di Indonesia disebabkan rasa ketidakpuasan terhadap perilaku penguasa dalam mengaplikasikan makna demokrasi. Makna demokrasi yang ditentukan dan ditafsirkan secara sepihak oleh Penguasa berbeda dengan pengertian dan kehendak rakyat, serta mengabaikan kebenaran dan sikap terhadap manusia oleh penguasa pada masa Orde Baru. Secara mendasar reformasi ditafsirkan sebagai suatu upaya yang terorganisir dan sistimatis dari bangsa Indonesia untuk mengaktualisasikan nilai-nilai dasar demokrasi. ${ }^{1}$

Pemahaman tentang demokrasi secara benar adalah penting dilakukan, karena berdasarkan pemahaman tersebut orang akan melakukan tindakan atau perbuatan sesuai dengan pemahaman yang dimilikinya terhadap demokrasi. Oleh karena itu, pencarian dan pembentukan format demokrasi secara objektif ilmiah haruslah dilakukan. Pencarian makna demokrasi tersebut tidaklah semata-mata menjadi bidang kerja politik tetapi juga sangat berkaitan dengan hukum. ${ }^{2}$

Di Indonesia, pencarian makna demokrasi dan pembentukan formatnya dalam era reformasi di Indonesia dapat dilihat dari amandeman terhadap UUD $1945^{3}$ yang ditindak lanjuti dengan pembentukan undangundang sebagai ketentuan organiknya.

Ada dua hal yang substansial dari makna demokrasi bila dilihat dari kaca mata hukum, yaitu berkaitan dengan norma (a) cara memperoleh kekuasaan dan (b) bagaimana melaksanakan kekuasaan. Untuk memahami dan melihat demokrasi secara objektif ilmiah perlu dipahami tentang dua hal penting, yaitu

${ }^{1}$ Muladi, Demokratisasi, Hak Asasi Manusia, dan Reformasi Hukum di Indonesia, (The Habibie Center, Jakarta, 2002), him. 28.

${ }^{2}$ Secara teoritis, Penganuh politik terhadap hukum sangat terasa kuat sekali khususnya pada pemikiran yang menganut aliran legisme yang menyatakan di luar undang-undang tidak ada hukum. Berdasarkan ajaran Trias Politika, bahwa pembuat undang-undang adalah Dewan Perwakilan Rakyat yang pada dasarnya berasal dari politik. Oleh karena itu, berdasarkan aliran legisme ini wajar bila gejolak dan perkembangan di bidang politik mempengaruhi pula bidang hukum.

${ }^{3}$ Perubahan ketiga disahkan pada tanggal 10 November 2001. 
(a) teori tentang demokrasi sebagai dasar pandangan dan (b) penguasaan praktis terhadap realitas dengan seluruh dimensinya. Oleh karena itu, pemahaman terhadap ontologi demokrasi perlu dilakukan untuk memudahkan memformulasikannya dalam undang-undang maupun implementasinya dalam praktik politik pada suatu negara tertentu termasuk Indonesia dengan tujuan agar tercipta tujuan dan cita-cita suatu negara. Dari sudut pandang inilah, tulisan ini dinilai penting untuk melakukan kajian secara akademik.

Berdasarkan uraian di atas, permasalahan yang menarik untuk dikaji adalah apakah esensi yang ada dalam menentukan ontologi demokrasi, dan bagaimana pengaruh ontologi terhadap mekanisme atau tataran operasional demokrasi di Indonesia.

\section{Makna Demokrasi}

Pengertian kata demokrasi sangat berkaitan dengan bahasa. Pada masa kini, masalah bahasa adalah masalah yang paling menonjol dalam kefilsafatan di samping masalah etika sosial. ${ }^{4} \mathrm{Di}$ bidang etika sosial, apakah yang hendak diperbuat oleh masyarakat dewasa ini? Apakah harus diterima sepenuhnya? Ataukah harus digulingkan dan digantikan oleh masyarakat yang lain sama sekali? Ataukah dimungkinkan suatu jalan tengah?

Sementara itu, memahami demokrasi secara bahasa ada dua pokok, yaitu (a) arti kata-kata dan (b) arti pernyataan-pernyataan. Istilah demokrasi sering dipakai tanpa dipikirkan secara mendalam, sampai-sampai masing-masing peserta dalam suatu pembicaraan mempunyai pengertiannya sendiri-sendiri. Yang demikian ini juga berlaku terhadap analisis mengenai pernyataanpernyataan. Dalam hal ini, yang bersifat menentukan ialah bahwa orang dapat memilah-milah antara pernyataan deklaratif (pemberitaan), pernyataan optatip (harapan) dan pernyataan normatif. ${ }^{5}$ Oleh karena itu, untuk melihat ontologi demokrasi' perlu juga dikaji dari sisi bahasa.

Dari sudut arti kata-kata, demokrasi berasal dari kata demos yang artinya rakyat dan krotos yang artinya kekuasaan. Jadi demokrasi adalah kekuasaan rakyat.

Salah satu gagasan demokrasi yang paling awal adalah kesepakatan, ataupun persetujuan, yang dibuat oleh masyarakat Yahudi kuno dengan Tuhan mereka. Perjanjian yang pertama kali diketahui antara yang mengatur dan yang diatur. Adalah sangat sederhana. Sebagai imbalan atas janji Tuhan memberikan kedamaian, tanah yang subur, umat berjanji untuk mematuhi perintah etik TuhanNya. Ikatan di antara keduanya adalah keadilan. ${ }^{6}$ Dalam konteks ini, terlihat kedudukan manusia dengan Tuhan adalah sebagai penguasa dan yang dikuasai. Tuhan dan manusia dalam konsep demokrasi kuno berada pada posisi yang bebas dan seimbang. Pemikiran yang demikian lamakelamaan menghasilkan pemikiran dan

\footnotetext{
${ }^{4}$ Bernard Delfgaauw, FilsafatAbad 20, (Tiara Wacana Yogyakarta, 2001), hlm. 173-174.

${ }^{5}$ bid.

${ }^{6}$ RobertA.Dahl, Perihal Demokrasi Menjelajahi Teoridan Praktek Demokrasi Secara Singkat, (Yayasan Obor Indonesia, Jakarta, 2001), hlm. 24.
} 
diwujudkan dalam kenyataan kemasyarakatan bahwa kehidupan keduniaan dipisahkan dari kehidupan keagamaan. Lebih jauh lagi, perkembangan dalam hal menentukan kebenaran, pada awalnya adalah Tuhan kemudian berubah dan berkembang menjadi manusialah sebagai penentu dan penetap kebenaran berdasarkan rationya. Pengaruh pemikiran yang demikian ini menyebabkan dalam perkembangannya pemaknaan demokrasi sangat sarat dan terkait dengan kebudayaan suatu masyarakat tertentu. ${ }^{\text {? }}$

Pemaknaan demokrasi terkait aspek sosilogis, budaya dan nilai suatu masyarakat tertentu, oleh karenanya masyarakat mempunyai kedudukan dependen terhadap pemaknaan demokrasi sesuai dengan watak, kepribadian, budaya, keyakinan, dan nilai yang dianut masyarakat itu sendiri. Demokrasi tampak pada masyarakat yang menciptakannya dan diwamai oleh prinsip-prinsip hidup yang mereka pegang. ${ }^{8}$ Karena demokrasi merupakan produk langsung dari seluruh warganya, tidak ada satu pun masyarakat demokrasi yang mencapai sempurna tanpa mengubah cita-citanya menjadi kenyataan. ${ }^{9}$

Uraian di atas memberikan gambaran, bahwa demokrasi merupakan hasil rekayasa yang diciptakan oleh masyarakat itu sendiri. Berabad-abad lamanya mereka memberikan model pemaknaan kepadanya, menciptakan kesalahan fatal pada suatu saat, dikarenakan kehendak masyarakat itu sendiri. Dan mencapai perkembangan yang luar biasa pada saat yang lain juga atas kehendak masyarakat itu sendiri. Demokrasi adalah suatu produk, dan nama itu sebelumnya diartikan sebagai suatu sumber kekuasaan daripada suatu cara memerintah. ${ }^{10}$

Untuk melihat ontologi demokrasi yang sesungguhnya harusiah dianalisis melalui analisis bahasa yaitu berkaitan dengan bahasa pernyataan. Karena dari segi bahasa inilah akan didapati apa sesungguhnya demokrasi itu, dan dari segi ini pula dapat dilihat konsep demokrasi secara utuh dan menyeluruh sehingga dalam penerapannya dapat dipahami secara baik dan benar. Untuk mencapai sasaran yang demikian itu, maka analisis tentang demokrasi dari segi bahasa pernyataan menyangkut tiga hal, yaitu (a) bahasa pernyataan deklaratif (b) bahasa pernyataan optatip dan (c) bahasa pernyataan normatif. Di bawah ini akan dibahas satu persatu tentang ketiga bahasa pernyataan tersebut.

\footnotetext{
${ }^{7}$ Bur Rasuanto, Keadilan Sosial, Pandangan Deontologis Rawls dan Hebermas Dua Teori Filsafat Politik. Modem, (Gramedia Pustaka Utama, 2005), him. 211.

${ }^{-8}$ Konsekuensi bahwa demokrasi adalah produk masyarakat dari bagian kebudayaan maka dimungkinkan terdapat perbedaan makna demokrasi pada suatu masyarakat dengan masyarakat lainnya. Pemaknaan ini akan dipengaruhi oleh pengertian kebenaran, nilai, yang dianut oleh suatu masyarakat tertentu. Keyakinan masyarakat terhadap sesuatu yang benar sangat pula dipengaruhi oleh keyakinan masyarakat itu sendiri, yaitu kebenaran yang ditentukan oleh Tuhan, ada pula kebenaran yang di dasarkan oleh kemampuan akal manusia semata-mata terlepas dari Tuhan.

${ }^{9}$ Richard M.Ketchum (ed), Demokrasi Sebuah Pengantar, (Niagara, Yogyakarta, 2004), hlm. 9.

${ }^{10}$ Adam Kuper \& Jessica Kuper, Ensiklofedi IImu-IImu Sosial, (Raja Grafindo Persada, Jakarta, 2000), hilm. 214.
} 


\section{a. Demokrasi dari sisi bahasa pernyataan deklaratif}

Dalam demokrasi terdapat dua prinsip yang paling utama yaitu (a) otoritas politik merupakan ekspresi dari keadilan" (b) hanya ada satu sumber otoritas politik, yaitu masyarakat itu sendiri. ${ }^{2}$

Teori-teori tradisional memandang pemerintahan yang demokratis sebagai kondisi yang diperlukan untuk kebebasan manusia. Di sini kebebasan dipahami dalam arti bebasnya setiap individu melakukan pilihannya tanpa gangguan dari pihak luar. Prinsip utamanya adalah kebebasan yang sama di dalam hukum, yang mencakup kebebasan sipil dan hak politik. Dengan demikian, demokrasi ditafsirkan sebagai tatanan politik yang memaksimalkan kebebasan dan diciptakannya sendiri aturan yang diperlukan bagi tatanan sosial, yang semua itu ditentukan melalui proses kesepakatan timbal balik. ${ }^{13}$ Kebebasan yang. dianut dalam teori demokrasi tradisional menyangkut kebebasan dari halangan dan gangguan dari luar, kebebasan yang demikian ini disebut sebagai kebebasan negatif sebagai dasar teori demokrasi individualis liberal. Goul menulis kebebasan yang demikian itu tidaklah cukup dalam suatu demokrasi yang sesuai dengan zaman abad ke-20. Menurutnya kebebasan harus ditambah dengan kebebasan positif yaitu kebebasan untuk mengembangkan diri. ${ }^{14}$
Demokrasi- hanya dimungkinkan jika masyarakat dapat mengakui kepentingankepentingan sebagian orang. maupun masyarakat yang lain, dan mengorganisir diri untuk tindakan politis tertentu. Jadi, demokrasi adalah government of by and for the people. Pernyataan ini adalah berkenaan dengan pernyataan yang bersifat deklaratif. Dari sisi ini, inti demokrasi ini terdapat dua hal pokok, yaitu (a) asal kekuasaan dan (b) melaksanakan kekuasaan dalam pemerintahan. Kedua hal tersebut, kekuasaan haruslah diramu dari dan untuk dipersembahkan kepada rakyat. Dalam pengertian rakyat terdapat pula beberapa hal yang paling mendasar, yaitu nilai yang dianut rakyat yaitu kebenaran menurut rakyat, budaya rakyat, kepentingan dan kebutuhan rakyat, kepemilikan rakyat, dan hak hidup rakyat. Sebagai contoh kebudayaan manusia pantai biasanya di mana-mana, di Barat, Timur, Utara, Selatan, cenderung demokratis, karena mereka menghayati dunia sehari-hari dengan horizon yang luas, berkontak dengan orangorang seberang yang bercakrawala bermacam-macam. Sehingga mental mereka sudah berabad-abad serba terbuka dalam suatu penghayatan realitas yang pluriform. Demikian pun terhadap bangsa-bangsa maritim biasa bersifat terbuka. Berbeda dengan manusia pegunungan atau pedalaman, biasa cenderung lebih tertutup, sempit terkurung dalam batas-batas hutan dan ladang yang relatif homogen dan uniform

${ }^{11}$ Istilah keadilan dalam konteks ini lebih diartikan sebatas pada persamaan. Lihat Jalaluddin Rahmat, Islam dan Kekuasan:Aktor atau Instrumen? dalam M.Imam Aziz dkk, "Agama Demokrasi \& Keadilan", Op.cit., hlm. 63.

${ }^{12}$ Richard M. Kitchum, Op.cit., hlm. 36-37.

.${ }^{13}$ Carol C.Gould, Demokrasi Ditinjau Kembali, (Tiara Wacana Yogyakarta, 1993), hlm. 31

${ }^{14} \mathrm{Ibid}$., hlm. 5 
dunia dan subjek-subjek pergaulannya. Mereka cenderung lebih feodal, apalagi kalau mata pencaharian mereka pertanian. ${ }^{15}$

Contoh lain adalah demokrasi yang dianut di Amerika Serikat. Banyak orang Amerika bisa memberikan alasan rasional mengenai mengapa demokrasi lebih baik dibanding tirani, atau mengapa sektor swasta bisa melakukan segala hal secara lebih baik ketimbang pemerintahan besar. Mereka mengatakan hal ini jelas berdasarkan pengalaman mereka sendiri maupun keyakinan dari idiologi-jdiologi politik dan ekonomi yang lebih luas sebagai bagian dari pendidikan umum mereka. Di sisi lain; tentunya jelas bahwa orang-orang Amerika mengadopsi sikap-sikap ini tanpa banyak memikirkan untuk mewariskannya pada anakanak mereka. Amerika dianggap memiliki pendirian kesadaran diri dan rasional yang sangat tinggi, namun penerimaan generasigenerasi Amerika selanjutnya terhadap prinsipprinsip pendirian itu bukan karena prinsipprinsip itu memberi pertimbangan yang sama sadarnya pada mereka seperti halnya Founding Father, tetapi karena prinsip-prinsip itu sudah menjadi tradisi. Oleh karenanya, ketika menggambarkan Amerika sebagai pemilik budaya demokratis atau budaya pasar bebas, yang mereka maksudkan adalah orang-orang Amerika yang menghargai individualisme, memiliki ketenangan dalam menjaga persamaan dan kecenderungan tidak percaya pada pemerintah dan otoritas yang besar. ${ }^{16}$

Dalam karya klasik Yunani yang berjudul polis, demokrasi adalah nama suatu konstitusi (sistem pemerintahan) di mana masyarakat yang lebih miskin bisa menggunakan kekuasaan untuk membela kepentingan mereka yang acapkali berbeda dari kepentingan kaum kaya dan para bangsawan. ${ }^{17}$

Demokrasi dapat dikenali dengan adanya unsur-unsur kedaulatan rakyat, pemerintahan mayoritas, perlindungan minoritas, menyenangkan, kemerdekaan yang dijamin undang-undang, partisipasi dalam perumusan kebijakan di setiap tingkatan, persamaan hak dan sebagainya. Prinsip demokrasi yang demikian ini selalu berubah untuk masyarakat yang juga selalu berubah dalam upaya menyempurnakan konstitusi. Demokrasi merupakan sebuah slogan yang sangat menggoda karena menjanjikan suatu bentuk pemerintahan di mana pemerintah dan yang diperintah berdampingan dengan rakyat yang berkuasa secara harmonis sehingga hanya sedikit pemerintahan yang diperlukan. Karenanya demokrasi dikaitkan dengan cita-cita kebebasan. ${ }^{18}$

Demokrasi sebagai rekayasa masyarakat yang terkait dengan budaya juga telah diungkapkan oleh Moh. Hatta. Menurutnya, citacita demokrasi di Indonesia adalah kolektivisme. Karena kolektivisme menurutnya yang mendasari demokrasi asli Indonesia. Kedaulatan rakyat atau demokrasi itu bukan hal asing bagi Indonesia. la ada di lapisan bawah, yaitu di lapisan masyarakat bawah. Demokrasi

${ }^{15}$ YB Mangunwijaya, Kosmologi Baru, Agama dan Demokratisasi Bangsa, dalam M.Imam Aziz dkk, "Agama Demokrasi \& Keadilan", (Gramedia Pustaka Utama, Jakarta, 1993), hlm. 10

${ }^{16}$ Francis Fukuyama, Trust, (Qalam Yogyakarta, 2002), him. 56-57.

${ }^{17}$ Adam Kuper, Log. Cit.

${ }^{18} \mathrm{Ibid.,} \mathrm{hlm.} 215$. 
Indonesia ditandai dengan tiga elemen yaitu (a) rapat, (b) masa protes, dan (c) tolong menolong atau kolektivisme. Rapat adalah tempat rakyat atau urusan rakyat bermusyawarah dan mufakat tentang segala urusan yang bersangkutan dengan persekutuan hidup dan keperluan bersama. Hal ini dalam demokrasi Barat sama artinya dengan menentukan kebenaran dan sikap terhadap manusia. Dari segi bahasa hal ini berkenaan dengan pernyataan normatif.

Masa protes adalah hak untuk membantah dengan cara umum segala peraturan negeri yang dipandang tidak adil. Ini mencakup hak rakyat untuk bergerak dan berkumpul dengan bebas. Bagi Hatta tidak ada demokrasi jjka tidak ada hak rakyat mengadakan protes bersama. Hal yang demikian ini sama maknanya dengan kebebasan dalam demokrasi Barat. Dan hal ini berkenaan dengan bahasa pernyataan normatif.

Tolong menolong artinya rakyat saling tolong menolong dalam kerja, dalam kesulitan, dalam pergaulan hidup sehari-hari. Hal ini dalam demokrasi Barat sama dengan mencapai kesenangan hidup atau persamaan. Pernyataan yang demikian itu, dari segi bahasa disebut dengan bahasa pernyataan optatip.

Pada tataran konsep, secara formal inti demokrasi dalam artian pernyataan deklaratif adalah berkenaan dengan asal kekuasaan dan melaksanakan kekuasaan dari, oleh dan untuk kepentingan umum, rakyat. Dalam tataran operasional, titik tekannya dapat diberikan kepada satu orang, sebagian orang; atau kepada banyak orang sepanjang kekuasaan itu diperuntukan untuk kepentingan umum. Penentu titik tekannya dalam operasional adalah didasarkan pada nilai dan budaya yang dianut oleh masyarakat tertentu.

Pada suatu masyarakat tertentu yang menganut nilai bahwa manusia tercipta dengan kemampuan dan yang berbeda, baik dari segi kemampuan intelektual, atau kelebihan lainnya yang berbeda dari orang kebanyakan diberi hak untuk mewakili orang banyak untuk menentukan dan menjalankan kepentingan orang banyak atau kepentingan umum. Dari segi operasionalnya kekuasaan diperoleh dan kekuasaan dijalankan diberikan kepada satu orang atau beberapa orang tertentu. Dari sini akan melahirkan demokrasi perwakilan.

Pada suatu masyarakat tertentu adakalanya dianut bahwa perbedaan kelompok dalam suatu masyarakat, maka dominasi kelompok menentukan bagaimana kekuasaan diperoleh dan bagaimana kekuasaan dijalankan. Pada masyarakat yang menganut nilai demikian ini akan melahirkan demokrasi pluralisme. Dari segi operasionalnya titik tekannya diberikan kepada sekelompok orang atau beberapa orang tertentu.

Sebaliknya pada suatu masyarakat lainnya, yang menganut nilai bahwa semua orang dipandang sama satu sama lain, maka secara operasional akan melahirkan demokrasi langsung yang titik tekannya diberikan kepada semua orang tanpa kecuali. Dengan konsekuensi kekuasaan diperoleh dan dijalankan untuk semua orang, atau orang banyak. Demokrasi yang demikian ini adalah demokrasi suatu bentuk pemerintahan yang mengikutsertakan seluruh anggota masyarakat dalam pengambilan keputusan yang menyangkut soal-soal kenegaraan dan kepentingan bersama. ${ }^{19}$

${ }^{19}$ Cipta Adi Pustaka, Ensiklopedi Nasional Indonesia, (jilid 4, Jakarta, 1989), hlm. 293. 
Bentuk demokrasi modern berkembang sejak abad ke-17 dimulai pecahnya Revolusi Industri yang mengakibatkan Revolusi Perancis dan Revolusi Amerika. Setelah dicetuskannya konsep hak asasi manusia dan hak politik, teori dan bentuk demokrasi semakin berkembang kearah demokrasi perwakilan yang sebelumnya berkembang adalah demokrasi langsung. ${ }^{20}$

Arif Budiman, membedakan demokrasi menjadi tiga. ${ }^{21}$ Pertama, demokrasi terjadi bila terdapat suasana kebebasan. Semua warga bebas berpendapat, berorganisasi, mengkritik dan sebagainya. Hal ini terwujud, apabila pemerintah telah kuat dan masyarakat sipil lemah. Dalam keadaan seperti itu pemerintah akan berkata, "Baiklah, demokrasi. Toh tidak akan membahayakan apa-apa". Dengan demikian demokrasi terjadi, namun sifatnya berupa pinjaman penguasa. Suatu saat kalau kritiknya terlalu keras dan mengancam pemerintah, demokrasi itu bisa ditarik kembali. Ini namanya demokrasi pinjaman. Kedua, demokrasi akan terjadi kalau ada pluralisme di tingkat elite, misalnya terjadi konflik di antara mereka. Kalau masyarakat mengkitik pihak yang satu, pasti akan dibela oleh pihak yang lain dan sebaliknya. Demokrasi jenis inipun sifatnya sementara. Kalau kelompok yang satu sudah menang, atau kemudian berkoalisi, ya kembali lagi tidak demokratis. Ini namanya demokrati terbatas. Oleh karenanya keduaduanya adalah bentuk demokrasi yang semu, karena yang terjadi adalah penguasa yang kuat berhadapan dengan masyarakat yang lemah.
Ketiga, adalah demokrasi yang asli, dimana demokrasi terjadi masyarakat bersatu dan menjadi kuat untuk kemudian dapat mengimbangi kekuasaan. Jadi untuk memperjuangkan demokrasi, kita tidak perlu meminta-minta kepada penguasa. Jadi demokrasi yang asli adalah ada kekuatan yang seimbang antara pemerintah dengan civil society.

Untuk memperoleh makna sejati demokrasi dari segi bahasa pernyataan tidaklah mempertentangkan antara pemerintah dengan yang diperintah, -melainkan menetralisir kedudukan keduanya dalam bentuk bagaimana kekuasaan diperoleh dan bagaimana mempergunakan kekuasaan. Makna demokrasi dari segi bahasa pemyataan deklaratif adalah bersifat universal namun dalam tataran operasionalnya adalah parsial. Makna demokrasi dari segi bahasa pemyataan deklaratif ini dalam tataran konsep berlaku universal, namun dalam tataran operasionalnya adalah bersifat parsial.

\section{b. Demokrasi dari sisi bahasa pernyataan optatip}

Hakikat demokrasi adalah the ruled rules the ruler by the rule. Jadi hakikat demokrasi ialah yang diperintah mempunyai supremasi kekuasan untuk menentukan atau sekalipun mengganti yang memerintah (Pemerintah) yang tidak dapat mewujudkan kehendaknya atau tujuannya dan cita-citanya. Sedangkan tujuan akhir demokrasi adalah kebahagiaan hidup. ${ }^{22}$ Kebahagiaan hidup inilah yang dari

\section{$20 \mathrm{Jbid}$}

${ }^{21}$ ArifBudiman, Agama, Demokrasi dan Keadilan, dalam Iman Aziz dkk, "Agama, Demokrasi dan keadilan", (Gramedia Pustaka Jaya, Jakarta, 1993), him. 26

22 Sukarna, Kekuasaan Kediktatoran dan Demokrasi, (Alumni Bandung, 1981), hlm.63. 
segi bahasa sebagai bahasa pernyataan optatip atas pengertian demokrasi .

Kebahagiaan hidup sebagai bahasa pernyataan masih dalam tataran umum dan abstrak yang merupakan pengertian bersifat universal. Terjadinya perbedaan tentang arti kebahagiaan hidup pada tataran operasionalnya. Dari segi operasional ada tiga realitas yang dapat dijadikan dasar tercapainya kebahagiaan hidup, yaitu (a) terpenuhinya kebutuhan materiil (b) terpenuhinya kebutuhan batin (c) terpenuhinya kebutuhan materiil dan spirituil. Penentuan prioritas pemenuhan kebutuhan ini berdampak pada pengertian operasional dari istilah demokrasi. Dan untuk menentukan prioritasnya digantungkan kepada nilai yang dianut oleh suatu masyarakat tertentu. Sehubungan dengan hal ini, maka demokrasi dari segi pencapaian kebahagiaan hidup dalam penerapannya sangat beragam tergantung dari bentuk kesenangan hidup yang ingin dicapai serta bagaimana mewujudkan kesenangan hidup itu sendiri. Jelasnya pasang surut operasional dari pengertian demokrasi sangat ditentukan oleh rakyat atau suatu masyarakat berkaitan dengan kesenangan hidup yang ingin digapainya.

Dalam praktiknya bentuk demokrasi diwarnai oleh kebutuhan dan keadaan masyakarat khususnya yang berkaitan dengan tujuan kesenangan hidup yang ingin dicapainya. Masing-masing masyarakat dunia mempunyai persepsi tersendiri tentang kesenangan hidup. Pada suatu masyarakat tertentu menekankan pada kebutuhan materil saja dan menyingkirkan kebutuhan spiritual, tetapi ada pula masyarakat yang mendahulukan kebutuhan spiritual ketimbang kebutuhan materiil, dan ada pula masyarakat yang memenuhi kebutuhan keduanya secara seimbang. Secara teoritis sebagaimana terbukti ada tiga buah model teoritis demokrasi, yakni (1) individualisme liberal, yang terwujud dalam demokrasi ekonomi pasar bebas. (2) pluralisme, teori demokrasi politik yang memandang konflik kepentingan antar kelompok terwadahi melalui mekanisme kepartaian dan pemilihan umum yang teratur hal lebih menekankan pada hak-hak politik, dan (3) teori sosialis holistik, yang mengkonsepkan demokrasi sebagai sistem politik dan ekonomi yang tersentralisasi, yang dengan sistem ini masyarakat sebagai keseluruhan menerapkan kontrol sosial tidak hanya terhadap wilayah politik melainkan juga terhadap produksi dan distribusi barang.23

Pada suatu masyarakat tertentu, kesenangan hidup ditentukan oleh terpenuhi dan.tercukupinya kebutuhan materiil. Bila ini yang di anut, maka demokrasi disalurkan dalam upaya memenuhi kebutuhan materiil dan yang menjadi titik tekannya adalah ekonomi. Konsekuensi dari paham yang demikian itu, demokrasi bertujuan untuk menciptakan kebebasan setiap orang untuk memenuhi kebutuhan ekonominya. Dari sini perwujudan demokrasi melahirkan demokrasi liberal dan ekonomi pasar bebas.

Pada demokrasi liberal ditemui beberapa kelemahan. Hal ini terlihat dari maksud dari persamaan adalah setiap manusia di pandang sama dalam hukum dan politik yang mengharuskan negara menjamin kebebasan sipil dan hak-hak politik yang sama bagi setiap individu. Berdasarkan pandangan yang demikian itu, konsepsi tentang manusia

${ }^{23}$ Carol C.Gould, Op.cit., hlm. 92-93. 
sebagai individu yang asosial dan egois, yang motivasi utamanyá dalam bertindak adalah pemenuhan kepentingan sendiri. Pandangan yang demikian ini tidak memperhatikan koperasi sosial atau kepentingan umum dari semua individu, kecuali mungkin hanya memandangnya sebagai agresi kepentingan pribadi tiap-tiap individu dan oleh karenanya sebagai alat untuk memuaskan kepentingan pribadi-pribadi tersebut. Pengingkaran terhadap keberadaan sosial sebagai perilaku antisosial dan keakuan adalah sesuatu yang tidak dapat diterima secara moral. ${ }^{24} \mathrm{Di}$ samping itu, demokrasi individualis ini mendukung dan membenarkan terjadinya ketimpangan kehidupan sosial dan ekonomi, dengan melindungi hak untuk memupuk kekayaan pribadi secara tak terbatas tanpa memperhatikan akibat sosialnya. ${ }^{25}$

Terhadap demokrasi pluralisme juga ditemukan kelemahannya. Kelemahan pertama, adalah berdasarkan pendekatan ini tidak saja tetap tidak menyentuh persoạlan ketimpangan di luar wilayah politik, tetapi memandang ketimpangan itu (yang diyakini realistis) sebagai ciri sistimatik dari persaingan kekuasaan politik di antara kelompokkelompok yang berkonflik. Kedua, dalam memahami demokrasi sebagai sarana kompetisi bagi elit demi kekuasaan politik, pandangan ini menyingkirkan perwakilan dan partisipasi politik, yang dalam bentuknya yang baik merupakan alat bagi pemilihan elit dan dalam bentuk buruknya merupakan ancaman bagi stabilitas sosial. Ketiga, ia gagal memberi jawaban yang memuaskan terhadap sosialitas atau kooperasi, kerena karakterisasi kelompok yang dibuatnya menjadikan pendekatan ini memandang kelompok tidak lebih sebagai agregasi individu yang hanya diikat olêh kepentingan pribadi para individu itu, yang untuk mewujudkannya membutuhkan kelompok. $^{26}$

Terhadap demokrasi sosialis juga ditemukan beberapa kelemahan yaitu: Pertama, ia gagal bertindak sesuai dengan norma teoritisnya sendiri tentang persamaan sosial dan ekonomi, dan sebaliknya mengarah kebentuk-bentuk hierarki dan stratifikasi sosial dan ekonomi. Kedua, karakteristik ekonomi komando dan perencanaan terpusat dalam masyarakat sosialis terbukti tidak efisien, dalam setiap kegiatan peningkatan produksinya untuk menyediakan kondisi bagi kemakmuran dan dalam mencapai tujuan distribusi yang merata. ${ }^{27}$

Pada suatu masyarakat tertentu mungkin kebutuhan materi bukan menjadi tujuan utama kebahagiaan, melainkan lebih bersifat rasa aman, tenteram, terlindunginya hak hak pribadinya, rasa aman dalam kehidupan bersama, terhindar dari penindasan dan tindakan kekerasan dari pihak lain, atau kebebasan dalam melaksanakan keyakinan dan kepercayaannya. Artinya titik tekan dalam mencapai kebahagian hidup itu lebih difokuskan pada hak-hak sipil dan politik dan pengembangan pribadi secara utuh.

Pada masyarakat lainnya ada yang menganut, bahwa kebahagiaan itu apabila tercapai kebutuhan materiil dan spritualnya.

\footnotetext{
${ }^{24}$ Ibid., hlm. 4

${ }^{25} \mathrm{lbid}$.

${ }^{26} \mathrm{Ibid.}$, hlm. 8-9.

${ }^{27}$ lbid. him. 6-7
} 
Hal ini sebagai realisasi dari hakikat manusia itu sendiri yang terdiri dari dua dimensi yaitu materi dan ruh. Kebahagiaan hidup yang sempurna apabila kebutuhan materi dan ruh dipenuhi secara seimbang dan sempurna. Untuk masyarakat yang demikian akan lahir demokrasi yang sejati yang mensimultankan kebutuhan ruh dan materi.

Dari konsep operasional tentang kesenangan hidup itu, watak dan karakter serta kualitas rakyat sangat menentukan pemaknaan demokrasi untuk pencapaian tujuan demokrasi itu sendiri. Dengan demikian bukan institusi yang primer harus menentukan sikap dan politik umum, melainkan manusia-manusianya, institusi adalah alat. Jadi demokrasi tidaklah bersumber pada sumber mata air institusi, tetapi selalu merupakan luapan kesadaran kultural suatu bangsa. ${ }^{28}$ Demokrasi tidak hanya berhubungan dengan institusi formal, tetapi juga dengan eksistensi nilai-nilainya dalam kehidupan sosial dan politik. ${ }^{29}$

Bagaimanapun juga kesenangan hidup haruslah dicapai sesuai dengan makna kebenaran yang dianut oleh suatu masyarakat tertentu.Penyalurannya dapat dilakukan melalui penyaluran di bidang politik, hak sipil, dan ekonomi. Penyaluran terhadap bidangbidang tersebut dapat dilakukan secara serentak, atau lebih menekankan pada salah satu bidang. Pilihan terhadap penyaluran demokrasi ditentukan oleh-kebutuhan, keinginan, dan pandangan masyarakat terhadap kesenangan hidup yang dianut dan akan dicapainya.

Dalam perkembangan terakhir abad ke XXI, kelihatannya penyaluran demokrasi diarahkan pada ketiga aspek, yaitu politik, ekonomi, dan hak-hak hidup yang sebagai wujud mencapai kesenangan hidup ${ }^{30}$ Dari sisi bahasa pernyataan optatip terlihat, bahwa demokrasi mempunyai makna yang universa! secara konsep tetapi pada tataran operasional dari kesenangan hidup terdapat perbedaan antara suatu masyarakat dengan masyarakat lainnya.

\section{c. Demokrasi dari sisi bahasa pernyataan normatif}

Substansi esensial dari makna demokrasi adalah berkenaan dua hal pokok, yaitu (a) sikap terhadap manusia dan (b) pemahaman terhadap kebenaran. Pemahaman terhadap dua hal ini dari segi bahasa pemyataan hal ini berkenaan dengan bahasa pernyataan normatif.

Dalam konsepsi kuno, demokrasi terkait dengan konsep kebenaran dan etika di samping: kekuasaan. Konsepsi inilah senjata pertahanan yang ampuh. Kebenaranlah yang masih akan, dan akan senantiasa membuat

\footnotetext{
${ }^{23}$ YB Mangunwijaya, Op.cit, hlm. 16

${ }^{29}$ MasykuriAbdillah, Demokrasidi Persimpangan Makna, Respons Intelektual Muslim Indonesia terhadap Konsep Demokrasi (1966-1993), (Tiara Wacana Yogya, 1999), hlm. 75

${ }^{30} \mathrm{Hal}$ ini dipengaruhi dari perhatian dunia terhadap penekanan perlindungan hak asasi manusia tidak saja diarahkan pada hak politik, hak sipil tetapi juga kepada hak ekonomi, sosial, dan budaya dalam upaya mencapai kesenangan hidup. Kesenangan hidup itu sendiri ada yang menonjolkan segi materi semata-mata, tetapi ada juga yang menonjolkan segi materi segaligus segi rohani. Penonjolan pencapaian kesenangan hidup ini juga dipengaruhi dari padangan terhadap manusia, ada manusia yang dipandang dari segi materi semata-mata tetapi ada yang memandang manusia adalah terdiri dari materi dan roh.
} 
manusia bebas. ${ }^{31}$ Oleh karena itu, pemahaman tentang makna manusia dan pemahaman tentang penentu dan asal kebenaran adalah hal mutlak dalam memberi warna makna demokrasi. Karena demokrasi berkaitan dengan sikap, maka demokrasi sangat berkaitan dengan budaya masyarakat tertentu, sebagaimana disebutkan pada uraian terdahulu. Karena demokrasi sebagai hasil budaya, maka pertanyaan yang perlu dilakukan analisis adalah siapa pembentuk kebenaran itu? Bagaimana kedudukan manusia di alam semesta ini? Pertanyaan itu semua berkenaan dengan cara pandang manusia mengenai dunia.

'Alija 'Ali izetbegovic menyebutkan ada tiga cara pandang integral mengenai dunia: (a) agama (b) material, dan (c) Islam. Ketiganya mencerminkan tiga kemungkinan dasariah, kesadaran, ${ }^{32}$ alam, dan manusia. Masingmasing ketiganya menemukan manifestasinya dalam agama Kristen, Materialisme, dan Islam. Segala jenis idiologi, filsafat, dan ajaranajaran, sejak zaman dahulu hingga sekarang, bisa direduksi ke dalam ketiga pandangan dasar mengenai dunia tersebut. Yang pertama mengambil eksistensi ruh sebagai titik tolaknya, yang kedua mengambil eksistensi materi, dan yang ketiga eksistensi simultan antara ruh dan materi. Jika hanya materi yang ada, maka materialisme adalah satu-satunya filsafat yang muncul. Sebaliknya, jika hanya ruh yang ada, maka manusia akan ada, dan hidup manusia tak akan bermakna tanpa agama dan moralitas. Islam adalah sebutan bagi kesatuan antara ruh dan materi, bentuk tertinggi dari manusia itu sendiri. Hidup manusia menjadi lengkap hanya jika ia meliputi keinginankeinginan fisik dan spiritual mereka. Semua kesalahan manusia, jika tidak disebabkan oleh penolakan religius terhadap pelbagai kebutuhan biologis manusia, maka pasti disebabkan oleh pengingkaran materialistik terhadap keinginankeinginan spiritual manusia. ${ }^{33}$

Cara memandang dunia dan manusia sebagaimana disebutkan di atas sangat mempengaruhi pemberian makna demokrasi dan pelaksanaan demokrasi itu sendiri. Dari dasar titik tolak pemikiran yang berbeda, tidak diragukan akan menghasilkan pemikiran tentang demokrasi yang berbeda pula, baik dari segi isi maupun mekanismenya.

Negara liberalisme menyingkirkan hak istimewa terhadap kebenaran. Keragaman pandangan bukan hanya perlu ditoleransi, melainkan juga harus didorong. Hanya dengan keragaman tersebut, pandangan yang benar, kalaupun ada, akan ditemukan. Upaya membatasi aneka dagangan intelektual yang dijajakan bakal berakibat pada pembatasan pilihan konsumen. Dan apabila pilihan terbatas, kitatakkan dapat berbelanja sesuka hati. Padahal, pasar gagasan harusnya dibuat seperti pasar bebas. Pembatasan hanya akan menghilangkan produk terbaik yang kita periukan. Masyarakat harus bisa secara langsung merasakan keragaman. ${ }^{34}$ Pandangan yang demikian ini

${ }^{31}$ Grayson Kirk, dalam Richard M.Ketchum (ed), Demokrasi Sebuah Pengantar, Op.cit., hlm. 6.

${ }^{32}$ Kesadaran adalah berkenaan dengan eksistensi manusia sebagaimana terbukti dari pemyatan Rene Decartes, yang menyebutkan cogito ergo sum. Saya berpikir, maka saya ada.

33 'Alija 'Ali Izetbegovic, Membangun Jalan Tengah Islam antara Timur dan Barat, (Mizan, Bandung, 1992), him. 21

${ }^{34}$ Oliver Leaman, Pengantar Filsafatislam, Sebuah Pendekatan Tematis, (Mzan, Ban-dung, 2002), hlm. 149 
dijabarkan dalam pemilihan langsung dalam memegang kekuasaan dalam pemerintahan. Jadi sisi materialisme yang lebih ditonjolkan, dan memandang politik adalah suatu gejala sosial (materialisme).

Paham liberal yang menjadi ideologi kehidupam masyarakat industri Barat saat ini sangat mempertahankan hak-hak individu dan cenderung melenyapkan argumen bahwa tindakan privat dapat mempunyai konsekuensi publik. Agama cenderung didorong eksis ke bidang privat dan seolah-olah tidak mempunyai konsekuensi publik. Dalam kasus ini ada pemisahan yang tegas antara agama dan negara. Dengan demikian kalau liberalisme membutakan diri terhadap argumen bahwa aktivitas privat mempunyai konsekuensi publik, maka secara otomatis liberalisme bermusuhan dengan klaim bahwa kelembagaan agama barang kali memiliki hak-hak dan fungsi-fungsi publik. ${ }^{35}$

Grayson Kirk mengatakan arti pentingnya suatu kebenaran, beliau mengatakan kekuatan semata-mata, walaupun mutlak diperlukan, tidaklah cukup. Mereka yang nampaknya membaktikan diri untuk penaklukan; apakah untuk tujuan politik ataupun militer, tidak terhalang seruannya oleh konsepsi kuno tentang kebenaran dan etika. Konsepsi ini dianggap sebagai gagasan borjuis yang usang. Namun, dalam perjalanan panjang, kecuali jika seluruh pelajaran sejarah itu salah, justru konsepsi inilah senjata pertahanan kita yang paling ampuh. Kebenaranlah yang masih akan, dan senantiasa, membuat manusia bebas. ${ }^{36}$

Bagaimana melihat makna dari sikap terhadap manusia adalah semua orang diciptakan sama, bahwa mereka semua dikaruniai oleh Sang Pencipta suatu hak yang tidak bisa dilanggar oleh orang lain, yang dengannya mereka hidup, bebas, dan mencari kebahagiaan. Untuk menjaga hak-hak ini, pemerintah dibentuk di antara sesama manusia, di mana kekuasaan mereka yang sebenarnya berasal dari persetujuan rakyat atau mereka yang diperintah. ${ }^{37}$

Sikap terhadap manusia bersumber dan sangat dipengaruhi oleh pemahaman terhadap makna manusia itu sendiri. Pemahaman terhadap manusia itu sebagai penentu kebenaran dan pusat kebenaran akan melahirkan sikap dan perlakuian terhadap manusia itu pula. Dari situ akan tertahir makna demokrasi yang dari segi substansinya ada dua hal, yaitu (a) persamaan, ${ }^{38}$ dan (b) gagasan bahwa pemerintah memerlukan persetujuan rakyat. ${ }^{39}$ Dua hal inilah yang

${ }^{35}$ Heru Nugroho, Negara, Pasar, dan Keadilan Sosial, (Pustaka Pelajar, Yogjakarta, 2001), hlm., 146.

${ }^{36}$ Dalam Richard M.Ketchum (ed), Op.cit., hlm. 6

${ }^{37} \mathrm{lbid} ., \mathrm{hlm} .22$.

${ }^{33}$ Dalam pemaknaan demokrasi persamaan yang dimiliki oleh setiap orang berakibat setiap orang mempunyai kebebasan khususnya dalam bidang ekonomi. Artinya persamaan politik diwujudkan bentuk kebebasan ekonomi. Sehingga ada sebagian penulis menyebutkan bahwa isi dari demokrasi adalah (a) kebebasan dan (b) rakyat adalah sumber kekuasaan. Merupakan suatu argumen yang terkenal di Amerika Serikat bahwa suatü klaim bagi kebebasan ekonomi sama sahihnya dengan klaim terhadap kebebasan politik, atau persamaan politik, Robert A.Dahl, Demokrasi Ekonomi Sebuah Pengantar, (Yayasan Obor Indonesia, Jakarta, 1992), him. 38

${ }^{39}$ RobertA.Dahl, Perihal Demokrasi Menjelajahi Teori dan Praktek Demokrasi Secara Singkat, (Yayasan Obor Indonesia, Jakarta, 2001), hlm. 30-31. 
mencirikan makna demokrasi yang amat berkaitan erat dengan hak asasi manusia yang menjadi teori yang dianut pada abad ke 18 dan ke-19. Tetapi apabila manusia dipahami sebagai makhluk Tuhan yang tunduk pada aturan-aturan 'Tuhan, máka akan lahir sikap demokrasi yang agamis, di mana pemilik kekuasaan adalah Tuhan. Semua manusia, baik pemimpin maupun yang dipimpin adalah bertujuan untuk menjalankan kebenaran yang ditentukan oleh Tuhan. Dalam hal ini, hak - istimewa kebenaran berada di tangan Tuhan. Jadi, pemimpin sebagai pemegang kekuasaan hubungan antar manusia dipilih dari seluruh rakyat. Jadi justifikasi penguasa atau pemimpin adalah sepanjang ia menjalankan tugasnya sesuai dengan kebenaran yang ditetapkan oleh Tuhan, apabila menyimpang rakyat berhak untuk menjatuhkannya. Dalam hal yang demikian, maka penguasa atau pemimpin harus memiliki kualitas manusia yang berdimensi dua, yaitu kualitas intelektualnya yang tangguh dan penghayatan agamanya yang bersih, jujur dan andal.

Menurut teori medieval, sebagaimana diungkapkan oleh Funkenstein yang dikutip oleh Leman, dalam bentuk terbaiknya negara akan dipimpin oleh imam yang sekaligus filosof. Statusnya sebagai imam merefleksikan kemampuannya memahami sifat agamis realitas. Tanpa kemampuan itu, ia tidak akan mampu mendirikan pemerintahan yang dapat memelihara segi ruhani masyarakat. Dia juga harus merupakan filosof yang mampu memahami bentuk pemerintahan yang sempurna secara rasional. Imam berkemampuan seperti seorang Nabi dalam melukiskan berbagai kebenaran agamis dan rasional secara imajinatif dan menarik kepada khalayak luas ${ }^{40}$ Negara yang demikian adalah bersifat organis. la adalah satuan yang diarahkan untuk memenuhi aspek-aspek materiil ataupun sprititual kehidupan manusia. Ruang lingkup individualistis karenanya, sangat dikekang. Karena hanya ada satu rute sejati menuju kebenaran yang sudah dipatok, upaya untuk mengabaikan atau menolaknya (dalam bentuk oposisi) menjadi sia-sia belaka. Mengabaikan dan menolak bahkan dianggap sebagai perilaku menyimpang. Dan individu seperti ini tidak boleh merusak harmoni negara ataupun menghalangi khalayak dari kebenaran.

Hal yang demikian itulah yang menjadi cita-cita politik Islam, Dalam Islam boleh saja ada toleransi dan keragaman pendapat, tetapi harus dibatasi. Membiarkan oposisi kebenaran berkembang sedemikian rupa sehingga mengungguli negara (peran) negara tidaklah tepat. Negara sudah semestinya bertindak kebapakan (paternal) terhadap warga dan mengarahkan mereka pada apa yang sebaiknya diperbuat. Toh, agama tidak lagi diperlukan apabila semua orang sudah tahu apa yang sebaiknya diperbuat. Dan bimbingan menjadi mubazir adanya. Justru karena bimbingan itu sedemikian pentingnya, mau tak mau negara harus berada di bawah naungan agama.

Teori medieval di atas, kelihatannya dapat dijadikan dasar dalam membentuk demokrasi di Indonesia, karena dinilai bersesuaian dengan pandangan falsafah bangsa Indonesia yang menempatkan Ketuhanan Yang Maha Esa sebagai causa

\footnotetext{
${ }^{40}$ Ibid., hlm. 148.
} 
prima dari sila-sila Pancasila lainnya. Ratio legis dari Ketuhanan Yang Maha Esa adalah identik dengan agama. Jadi dalam kajian akademis, dalam pandangan falsafah Pancasila negara dan agama adalah satu kesatuan yang tidak terpisahkan. ${ }^{41}$

Dari tiga bahasa pernyataan terlihat bahwa hal yang paling esensial dari makna demokrasi sebenarnya terletak pada bahasa pernyataan normatif yakni tentang kebenaran. Keberanan inilah yang akan mempengaruhi makna demokrasi dari segi bahasa pernyataan deklaratif maupun pernyataan optatif. Artinya kebenaran yang dianut oleh suatu masyarakat akan menentukan makna demokrasi dari segi bahasa pernyataan deklaratif dan bahasa pernyataan optatif. Oleh karena itu mekanisme demokrasi tidak dapat ditunggalkan dalam satu pengertian yang uniform, tetapi amat berbeda pada satu masyarakat tertentu dengan masyarakat lainnya.

\section{Simpulan}

Isi ontologi demokrasi mengandung tiga hal prinsip yaitu (a) kebenaran dan sikap terhadap manusia (b) mencapai kesenangan hidup dan (c) kebebasan manusia. Jadi, ontologi demokrasi adalah memperoleh dan menggunakan kekuasaan berkenaan sikap terhadap manusia dalam suatu kehidupan bersama demi mencapai kesenangan hidup yang didasarkan pada nilai kebenaran.

Ontologi demokrasi dalam tataran konsep berlaku universal, namun dalam tataran operasional ontologi demokrasi amat parsial yang sangat dipengaruhi oleh makna kebenaran dan makna manusia serta sikap terhadap manusia yang dianut oleh masyarakat tertentu. Oleh karena itu, dari tataran operasional demokrasi dari segi pernyataan deklaratif dan optatif dapat berubah-ubah mengikuti bahasa pernyataan normatif yaitu yang berkaitan dengan maknà kebenaran dan makna sikap terhadap manusia yang dianut oleh masyarakat tertentu.

Berdasarkan kajian akademis, adalah tidak bijaksana bila dalam tataran operasional, demokrasi diberlakukan secara universal. Misalnya menunggalkan konsep pemaknaan demokrasi secara operasinal berdasarkan demokrasi liberal saja ${ }^{42}$ atau sosialis saja atau bahkan pluralis saja. Situasi, kondisi, dan nilai kebenaran yang dianut suatu masyarakat adalah tolok ukur yang paling menentukan operasional demokrasi. Menghargai pemaknaan dan pelaksanaan demokrasi dari operasionalnya yang beraneka ragam itu adalah salah satu bentuk dari tindakan demokrasi yang sejati. Sebab demokrasi dalam tataran realitasnya sesungguhnya adalah menghargai keanekaragaman yang

${ }^{41}$ Secara empirik juga terlihat bahwa adanya keterkaitan antara agama dengan negara di Indonesia, ditandai banyaknya partai politik berbasis agama dan keberadaannya diakui oleh undang-undang yang berlaku di Indonesia.

${ }^{42}$ Sebagamana yang gencar dilakukan oleh Amerika Serikat dalam globalisasi saat ini, yang mencoba menunggalkan pemaknaan dan pelaksanaan demokrasi di seluruh belahan dunia melalui jalur budaya, ekonomi, hukum dan pendidikan. Menurut pakar pendidikan Amenika Serikat, DamonAnderson, pada Seminar Intemasional Bahasa dan Pendidikan Kunci Kehasilan Pencerdasan Bangsa Dalam Globalisasi yang diselenggarakan pada tanggal 12-13 Juli 2005 Unimed Medan, yàng menyatakan bahwaAmerika Serikat yang mempengaruhiglobalisasi dunia dengan kekuatan ekonomi, hukum, budaya, dan pendidikannya. 
ada. Bukankah keanekaragaman itulah sebenamya wujud kehidupan dunia yang objektif dan hal yang demikian itu adalah kebenaran yang esensial yang tak dapat dipungkiri.

Dengan demikian, tidaklah tepat bila demokrasi harus diformulasikan dalam suatu bentuk dan mekanisme yang seragam di seluruh dunia. Adalah tidak demokratis apabila menunggalkan pemaknaan dan penerapan demokrasi di seluruh dunia. Hal ini sangat bertentangan dengan ontologi dari demokrasi itu sendiri.

\section{Daftar Pustaka}

Adam Kuper \& Jessica Kuper, 2000, Ensiklopedi IImu-IImu Sosial, Raja Grafindo Persada, Jakarta.

Arif Budiman, 1993, Agama, Demokrasi dan Keadilan, dalam Iman Aziz dkk, "Agama, Demokrasi dan keadilan", Gramedia Pustaka Jaya, Jakarta.

'Alija 'Ali Izetbegovic, 1992, Membangun Jalan Tengah Islam antar Timur dan Barat, Mizan, Bandung.

Bernard Delfgaauw, 2001, Filsafat Abad 20, Tiara Wacana Yogyakarta.

Bur Rasuanto, 2005, Keadilan Sosial, Pandangan Deontologis Rawls dan Hebermas Dua Teori Filsafat Politik Modern, Gramedia Pustaka Utama.

Budiono Kusumohamidjojo, 2004, Filsafat Hukum Problematik Ketertiban yang Adi, Grasindo, Jakarta.

Carol C.Gould, 1989, Demokrasi Ditinjau Kembali, Tiara Wacana Yogyakarta.

Cipta Adi Pustaka, 1993, Ensiklopedi Nasional Indonesia, jilid 4, Jakarta.

Francis Fukuyama, 2002, Trust, Qalam, Yogyakarta.
Heru Nugroho,2001, Negara, Pasar, dan Keadilan Sosial, Pustaka Pelajar, Yogjakarta.

Jalaluddin Rahmat, 1993, Islam dan Kekuasan: Aktor atau Instrumen, dalam M.ImamAziz dkk, "Agama Dëmokrasi \& Keadilan". Gramedia Pustaka Jaya, Jakarta.

Jerry D.Gray, 2004, Fakta Sebenarnya Tragedi 11 September, Sinergi Publishing, Jakarta.

Jimly Asshiddiqie, 2004, Konstitusi \& Konstifualisme Indonesia, Mahkamah Agung RI kerjasama dengan Pusat Studi Hukum Tata Negara Fakultas Hukum Universitas Indonesia, Jakarta.

John L.Esposito,1990, - Islam dan Pembangunan, Rineka Cipta, Jakarta. Richard M.Ketchum (ed), 2004, Demokrasi Sebuah Pengantar, Niagara, Yogyakarta.

Robert A.Dahl, 1992, Demokrasi Ekonomi Sebuah Pengantar, Yayasan Obor Indonesia, Jakarta.

Robert A.Dahl, 2001, Perihal Demokrasi Menjelajahi Teori dan Praktek Demokrasi Secara Singkat, Yayasan Obor Indonesia, Jakarta.

Masykuri Abdillah,1999, Demokrasi di Persimpangan Makna, Respons Intelektual Muslim Indonesia terhadap konsep Demokrasi (1966-1993), Tiara Wacana Yogya.

Muchsin, Fadillah Putra, 2002, Hukum dan Kebijakan Publik, Analisis atas Praktek Hukum dan Kebijakan Publik dalam Pembangunan Sektor Perekonomian di Indonesia, Averros Press, Malang.

Muladi, 2002, Demokratisasi, HakAsasi Manusia, dan Reformasi Hukum di Indonesia, The Habibie Center, Jakarta. 
Sukarna, 1981, Kekuasan Kediktatoran dan Demokrasi, Alumni Bandung.

Sunyoto Usman, 2003, Pembangunan dan Pemberdayaan Masyarakat, Pustaka Pelajar, Jogjakarta.

Oliver Leaman, 2002, Pengantar Filsafat islam, Sebuah Pendekatan Tematis,
Mizan; Bandung.

YB Mangunwijaya,1993, Kosmologi Baru, Agama dan Demokratisasi Bangsa, dalam M.Imam Aziz dkk, "Agama Demokrasi \& Keadilan", Gramedia Pustaka Utama, Jakarta. 